\title{
The Italian National Strategy for Inner Areas (SNAI): A Critical Analysis of the Indicator Grid
}

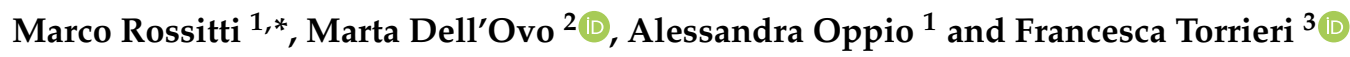 \\ 1 Dipartimento di Architettura e Studi Urbani, Politecnico di Milano, Via E. Bonardi 3, 20133 Milano, Italy; \\ alessandra.oppio@polimi.it \\ 2 Dipartimento di Architettura, Ingegneria delle Costruzioni e Ambiente Costruito, Politecnico di Milano, \\ Via G. Ponzio 31, 20133 Milano, Italy; marta.dellovo@polimi.it \\ 3 Dipartimento di Ingegneria Industriale, Università degli Studi di Napoli Federico II, Piazzale V. Tecchio 80, \\ 80125 Napoli, Italy; frtorrie@unina.it \\ * Correspondence: marco.rossitti@polimi.it
}

Citation: Rossitti, M.; Dell'Ovo, M.; Oppio, A.; Torrieri, F. The Italian National Strategy for Inner Areas (SNAI): A Critical Analysis of the Indicator Grid. Sustainability 2021, 13, 6927. https://doi.org/10.3390/ su13126927

\section{Academic Editors: Valentina}

Antoniucci, Giuliano Marella and Edwin H. W. Chan

Received: 30 March 2021

Accepted: 3 June 2021

Published: 19 June 2021

Publisher's Note: MDPI stays neutral with regard to jurisdictional claims in published maps and institutional affiliations.

Copyright: (c) 2021 by the authors. Licensee MDPI, Basel, Switzerland. This article is an open access article distributed under the terms and conditions of the Creative Commons Attribution (CC BY) license (https:// creativecommons.org/licenses/by/ $4.0 /)$.
Abstract: The National Strategy for Inner Areas (SNAI) is a public policy designed to tackle depopulation in inner areas, defined according to the distance from centers offering essential services. Such a policy's success is crucial to address the new challenges for planning brought to light by the COVID19 pandemic. In this sense, there is a need to adequately support its implementation by providing handy decision support tools, understanding the power balances among municipalities, and defining proper interventions. The Indicator Grid, already used by the SNAI for project areas selection, can answer this need. However, the Grid's application to support public policy at the municipality level requires reviewing some of its features, such as the indicators' large number and the impossibility of defining some of them at the municipal scale. Based on these premises, this paper aims at supporting inner areas policies by carrying out a critical analysis of the current SNAI Grid, aimed at improving its effectiveness. It relies on a hybrid methodology that merges qualitative data interpretations and statistical analyses. Thanks to this method, defining a parsimonious Grid by leaving its complexity and information level untouched is possible. The so-defined set of indicators can represent a valuable reference tool in pinpointing priorities for actions or selecting further territorial scopes from the SNAI perspective, even if it still brings some criticalities to be faced.

Keywords: SNAI Indicator Grid; hybrid methodology; public policies; decision support

\section{Introduction}

The COVID-19 pandemic has forced an accurate reflection about the leading urbanization model's crisis [1,2] and the need to place marginal areas at the core of new territorial sustainable development paradigms [3]. This reflection has immediately resulted in growing attention towards territorial cohesion policies that, starting from 2007 with the Lisbon Treaty, are at the core of European programs to reduce disparities between and within European countries, thus promoting a more balanced and sustainable development $[4,5]$.

In more detail, in the Italian context, the emerged debate has placed greater attention on inner areas, which, since 2014, are the focus of a national policy representing one of the most interesting laboratories and examples of the EU's territorial cohesion goal [6,7]: the National Strategy for Inner Area (SNAI).

Similar to the cohesion policies in other European countries [8-10], the SNAI focuses on marginal areas, intended as territories that have been cut off from the leading urbancentered development models over recent decades.

This strategy, aimed at tackling the ongoing marginalization and depopulation phenomena affecting Italian inner areas, has shown its potentialities in administrative, social innovation, and territorial transformation [11]. Thus, its crucial role in addressing the new 
challenges that emerged with the pandemic and promoting an effective transition towards sustainable development in planning issues is widely acknowledged [12,13].

However, its effective implementation still demands reliable and handy decision support tools, providing objective references to understand territorial dynamics and power balances among municipalities and support in defining effective interventions.

The SNAI Indicator Grid, used in the SNAI investigation process's desk phase to assess the different proposals for the project areas selection, stands as a helpful answer to this need. However, the Grid's application to support public policy at the municipality level requires reviewing some of its features, such as the indicators' significant number and the impossibility of defining some of them at the municipal scale.

Based on these premises, this paper aims at supporting inner areas policies by providing them with a comprehensive indicator set, stemming from a critical analysis of the current SNAI Grid towards its handiness and effectiveness.

After a brief overview of SNAI's contents and objectives, Section 2 delves into the SNAI Grid's description by explaining its structure, potentialities, and limits in supporting public policies at the municipality level. Based on the previous section's findings, Section 3 proposes the hybrid methodology that, merging qualitative data interpretations and statistical analyses, is used to review the original Grid by leaving its level of information and complexity untouched. Finally, in Section 4, the parsimonious Grid's possible value as a reference tool according to the SNAI perspective, such as its remaining criticalities and possible further improvements, is highlighted.

\section{The National Strategy for Inner Areas (SNAI)}

\subsection{Contents and Objectives}

The National Strategy for Inner Areas (SNAI) is an Italian public policy supported by national resources and European funds (FESR, FSE, and FEASR) [14]. It aims at tackling the negative demographic trends in some Italian marginal areas by promoting actions for local development and the rebalancing of welfare services [15].

The areas included in these straightforward national cohesion policies are defined as inner areas and identified as follows [16]:

- Significantly distant from the main centers offering essential welfare services (education, healthcare, and mobility);

- Endowed with significant environmental resources (water resources, agricultural systems, natural and human-made environment) and cultural resources (historical villages, craft centers);

- A diversified territory as a result of the different natural systems' dynamics and human activity.

More precisely, moving from this definition, together with the assumption that the distance from essential services heavily affects citizens' life, the Technical Committee for Inner Areas divides the territory into five zones (centers, peri-urban areas, intermediate areas, peripheral areas, ultra-peripheral areas) [17]. This division rests on an accessibility indicator, measured in minutes needed to reach the closest center, defined as a municipality or neighboring municipalities' aggregation, offering simultaneously: all the secondary education provision; hospitals with I level DEA; and Platinum, Gold, or Silver railway stations, according to the RFI classification [18].

According to this classification, inner areas include all the areas resulting as intermediate, peripheral, and ultra-peripheral. Thus, inner areas account for around $60 \%$ of the national territory, more than 4000 municipalities, and more than $20 \%$ of Italian residents [19].

Among them, starting from 2014, seventy-two project areas, grouping several municipalities classified as inner areas, have been selected for the SNAI's implementation (Figure 1). 


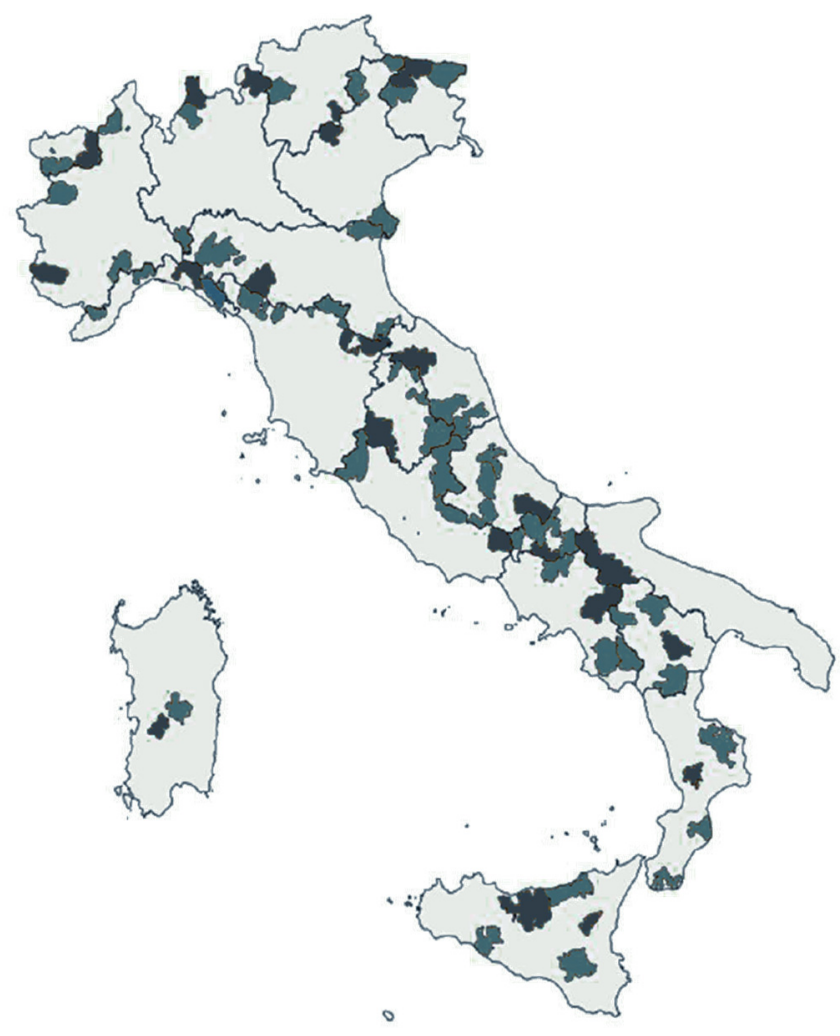

Figure 1. Seventy-two Italian project areas selected with the National Strategy for Inner Areas.

This selection resulted from a public investigation process based on multi-level cooperation among the national Technical Committee, responsible for SNAI's governance, regions, and local administrations. This investigation process consists of two different phases (Figure 2) [20]:

- A former desk phase for the area diagnosis. It involves the Technical Committee in assessing the various proposals to inner area projects submitted by the reference regions. This diagnosis process rests on an Indicator Grid, defined for the whole national territory, as an objective tool to evaluate the candidate areas' conditions;

- A latter on-field phase. At this point, the key elements that emerged from the area diagnosis are improved and enriched thanks to the direct interaction with the territory and its community.

Following such a process, the National Technical Committee issues an investigation document for each area, representing the functional and administrative fulfilment for starting the Area Strategy design process. This process ends with a framework program agreement (ApQ) for each project area, representing the implementation tool for inter-institutional cooperation. It establishes all the interventions to be conducted, the financial resources to cover them, their scheduling, and the related expected results [21]. 

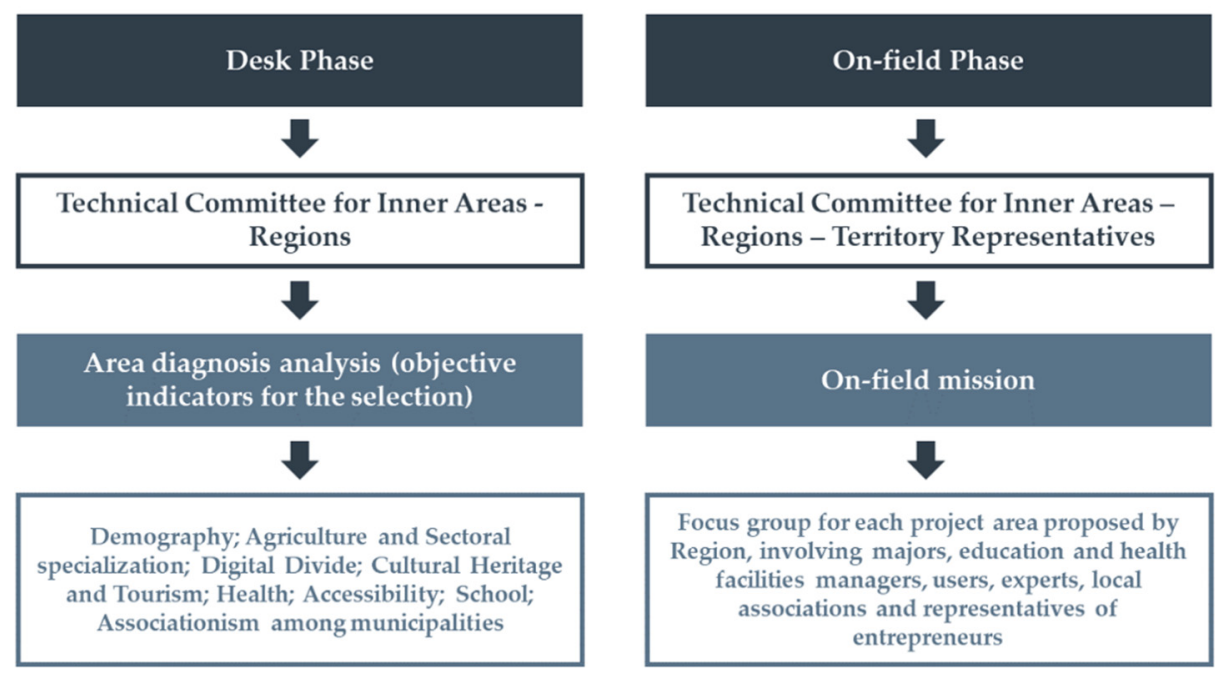

Figure 2. Inner areas selection process: main phases.

\subsection{An Indicator Grid for the "Area Diagnosis" Process}

As previously explained, the first step of the investigation process towards project areas selection, the so-called desk phase, is based on the SNAI Indicator Grid. It is a matrix that aims to understand inner areas' characteristics and compare different areas through quantitative indicators, equal for all the regions and the project areas involved. Indeed, it includes both context variables (i.e., demographic indicators) and result variables, aimed at measuring essential services' qualities (i.e., teaching mobility, time needed for $118^{\prime}$ s arrival) or specific activities' economic success (i.e., accommodation rate) [22].

The Grid stems from a conjunct work of various Italian ministries and other public entities. The collaboration among institutions with different knowledge and action fields finds its reason in the SNAI Indicator Grid's structure. Indeed, it is articulated in nine sections:

- Main characteristics;

- Demography;

- Agriculture and sectoral specialization;

- Digital divide;

- Cultural heritage and tourism;

- Health;

- Accessibility;

- School;

- Cooperation among municipalities.

Each section includes several indicators to provide an exhaustive overview of project areas' conditions. If applied to support decisions in the SNAI perspective, the utility of a so-defined tool lies, first, in its capacity to yield a picture of inner areas' need through an objective and straightforward framework, to be integrated with qualitative considerations and evidence from the on-field missions. Second, the availability of objective measures explaining inner areas' conditions can represent a good reference for setting goals to be reached and for their monitoring in performance terms.

Based on the keen awareness of such a tool's potentialities, the willingness to use it as support for public policies at the municipality level in the SNAI context spontaneously moves from an in-depth analysis of the indicators composing the SNAI Grid to detecting some weaknesses emerging about its new application (Table A1). They can be listed as follows:

- A large number of indicators makes it hard to collect the necessary information to update the Grid or apply it at the municipality level to understand the power balance 
among municipalities in the same project area. The SNAI Grid, indeed, consists of 161 indicators;

- The difficulty of collecting all the data. The Grid, in its current state, requires much information which is not easily accessible and needs cooperation among different public institutions. The related required efforts, if appropriate for the project areas selection in the SNAI launch phase, can prevent the Grid's extensive use as practical support for decisions;

- A large amount of information to manage and the difficulties in accessing data sources hinder comprehensive qualitative analysis processes geared towards better investigating relations among different variables and delving into territorial dynamics. Indeed, without qualitative interpretation, flanking the objective qualitative assessment, the Indicator Grid boils down to an uncritical collection of variables, making limited sense when dealing with planning issues, widely acknowledged as wicked problems [23];

- The selected indicators display some biases emerging when dealing with the cultural heritage and tourism section. Indeed, the indicators composing this section of the Grid reflect a partial and limited vision of cultural heritage as a tourism attraction. In more detail, all the indicators belonging to the Grid's sections are only measures of tourist flows related to cultural heritage. On the contrary, there is no indicator considering built heritage use and conservation state or describing the ongoing enhancement initiatives in the inner areas. Again, the cooperation among municipalities only includes indicators concerning the relations among municipalities, without considering other kinds of synergies within local communities, which can play a fundamental role in pursuing the place-based approach at SNAI's core [24];

- Some Grid indicators are conceived for the inner areas' territorial dimension and cannot be applied at the municipality scale.

\section{A Hybrid Methodological Approach towards SNAI Indicator Grid Review}

The highlighted drawbacks need to be overcome to trigger the SNAI Indicator Grid's potentialities and to make it a straightforward and handy decision support tool for SNAI implementation. In this light, starting from the most relevant Grid limit, which lies in its large number of indicators, this paper sets a hybrid methodological approach towards its review.

This approach merges qualitative data interpretations and statistical analyses to avoid redundancy of the variable set and keep only the relevant ones for the SNAI purposes. The logic behind this approach can be found in the law of briefness, whose reflection in data science is represented by the use of parsimonious models, allowing a significant explanatory power of a dataset to be reached with a minimum number of variables $[25,26]$.

Going into detail, the proposed methodological approach is divided into three different steps, as shown in Figure 3. 


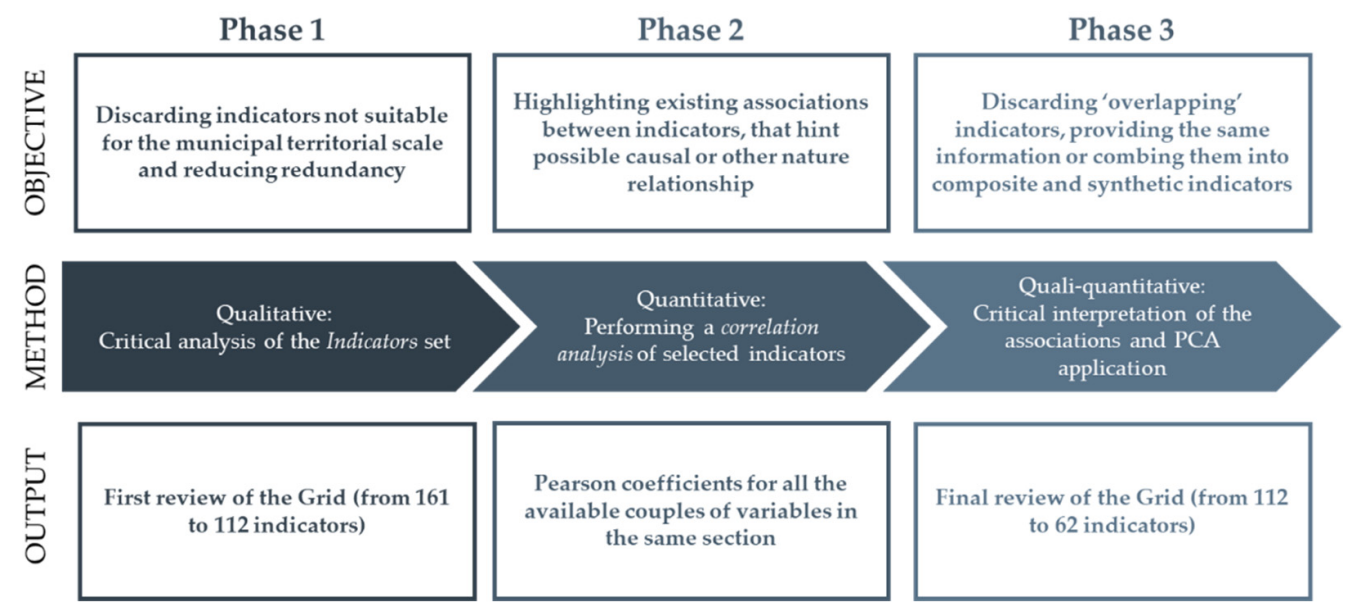

Figure 3. Hybrid methodological approach towards SNAI Indicator Grid's review.

The first qualitative phase is based on a critical analysis of the indicator set. This preliminary but essential step has a dual purpose:

- On the one hand, to discard the indicators referring to the inner area territorial scale, thus allowing turning the SNAI Grid into a decision support tool applicable at the municipality scale and, therefore, able to provide an in-depth understanding of territorial dynamics and power relations among municipalities belonging to the same inner areas. Indeed, the Grid includes several indicators-i.e., the number of municipalities in 2011—which lose their meaning when defined at the municipal scale.

- On the other hand, to reduce the redundancy of the Grid, intended as the presence of the same piece of information in two different indicators [27,28]. In more detail, this is mainly conducted by addressing temporal redundancy and, thus, rejecting the indicators occurring twice with a different time horizon, when their combined use does not pitch in the interpretation of the phenomena under investigation. Indeed, the latest version of the Grid, obtained by updating the first one issued in 2014, displays the addition of several indicators, equal to the already existing ones, but with a different time reference.

This qualitative phase is followed by a second quantitative step, resting on the selected indicators' statistical analysis. This step is geared towards highlighting existing associations among variables, hinting at possible causal or other nature associations. In particular, a Pearson correlation analysis is performed among each couple of variables within each Grid category. It grounds the values provided for each indicator at the project area scale by the Technical Committee for Inner Areas [29].

Correlation analysis is a bivariate analysis method that measures the strength of association between two variables and describes its direction [30]. Its output lies in a coefficient ranging from -1 to 1 , where the coefficient's signs convey the relationship's direction, and its numerical value describes the degree of association between variables [31-33].

Coming to the SNAI Indicator Grid, correlation analysis rests on the numerical data provided by each region, together with the proposals for their inner areas in 2014 and then updated in 2017. A Pearson r correlation coefficient is calculated through the software Excel for each pair of selected indicators after the first phase within each Grid category. It hints at a potential linear relationship between two variables and a possible index of a causal relationship. According to this coefficient, given two indicators $X$ and $Y$, it is possible to state the following:

- If $0<\left|r_{x y}\right|<0.4$, the variables $X$ and $Y$ are weakly correlated;

- If $0.4<\left|r_{x y}\right|<0.6$, the variables $X$ and $Y$ are moderately correlated;

- If $0.6<\left|r_{x y}\right|<0.8$, the variables $X$ and $Y$ are markedly correlated;

- If $0.8<\left|r_{x y}\right|<1.0$, the variables $X$ and $Y$ are strongly correlated. 
In this way, correlations help to highlight the indicators' pairs and, therefore, to better analyze them considering a marked or strong correlation.

With this aim, the described quantitative phase, based on the statistical correlation method, introduces a third and final hybrid step to complete the SNAI Indicator Grid review. Since marked and strong correlations hint at causal or other nature associations between indicators, a critical interpretation of these associations becomes necessary for a double purpose: to eventually discard "overlapping" indicators that provide the same information or to combine them into fewer composite indicators when it is consistent with their nature.

Concerning the opportunity to combine the Grid indicators into composite indicators, principal components analysis can support this research's effort. Principal component analysis (PCA) is a widespread multivariate data analysis technique [34,35]. It enables explaining the variance of an observed dataset through few linear combinations of the original data, describing most of the data's variation and uncorrelated [36]. If the analysis's objective is to reduce a set of indicators, like in the SNAI Grid case, PCA can provide some degree of economy by using few variables. However, it is not always possible to reduce the variables' number through PCA: if the starting data are not correlated, the analysis has no value; otherwise, it can provide significant results when dealing with correlated variables.

After verifying the necessary assumptions for PCA application [37-41], the analysis moves to finding the eigenvalues $\lambda_{y}$ of the sample covariance matrix $C M$, which becomes the correlation matrix by standardizing the considered variables. Then, for each eigenvalue, the correspondent eigenvector, providing the loading factors that allow the original indicators' transformation into their principal components, is calculated.

To understand the number of principal components to be retained after the analysis to reduce the initial indicator set without losing information, it is possible to refer to different stopping rules [42]. This study resorted to the Kaiser criterion, consisting of dropping all principal components with an eigenvalue less than 1 [43]. This rule is justifiable as there would be no sense to consider a factor/principal component describing less variance than the one contained in one individual indicator.

\section{Application of the Hybrid Methodological Approach to the SNAI Indicator Grid}

The so-defined hybrid methodological approach was applied to all the different SNAI Grid sections, thus providing a parsimonious version of the Grid, including around 60 indicators (Figure 4). The figure below describes, in detail, the methodology's application with particular attention to some relevant sections of the Grid.

\subsection{The "Demography" Section}

The "demography" section includes thirteen indicators concerning residents' population structure and its variation over time in the seventy-two inner areas project (Table A1). The application of the proposed three-step hybrid methodology to this section of the Grid is described below. In more detail, it determines a fair rationalization in the original variable set.

\subsubsection{Phase 1: Critical Analysis of the Indicator Set}

This first step, performed for the "demography" section, shows a medium redundancy level due to some static indicators included twice with different time horizons. For this reason, a first review of the variable set, aimed at addressing this redundancy, was carried out by bringing the number of indicators from thirteen to nine (Table 1). 


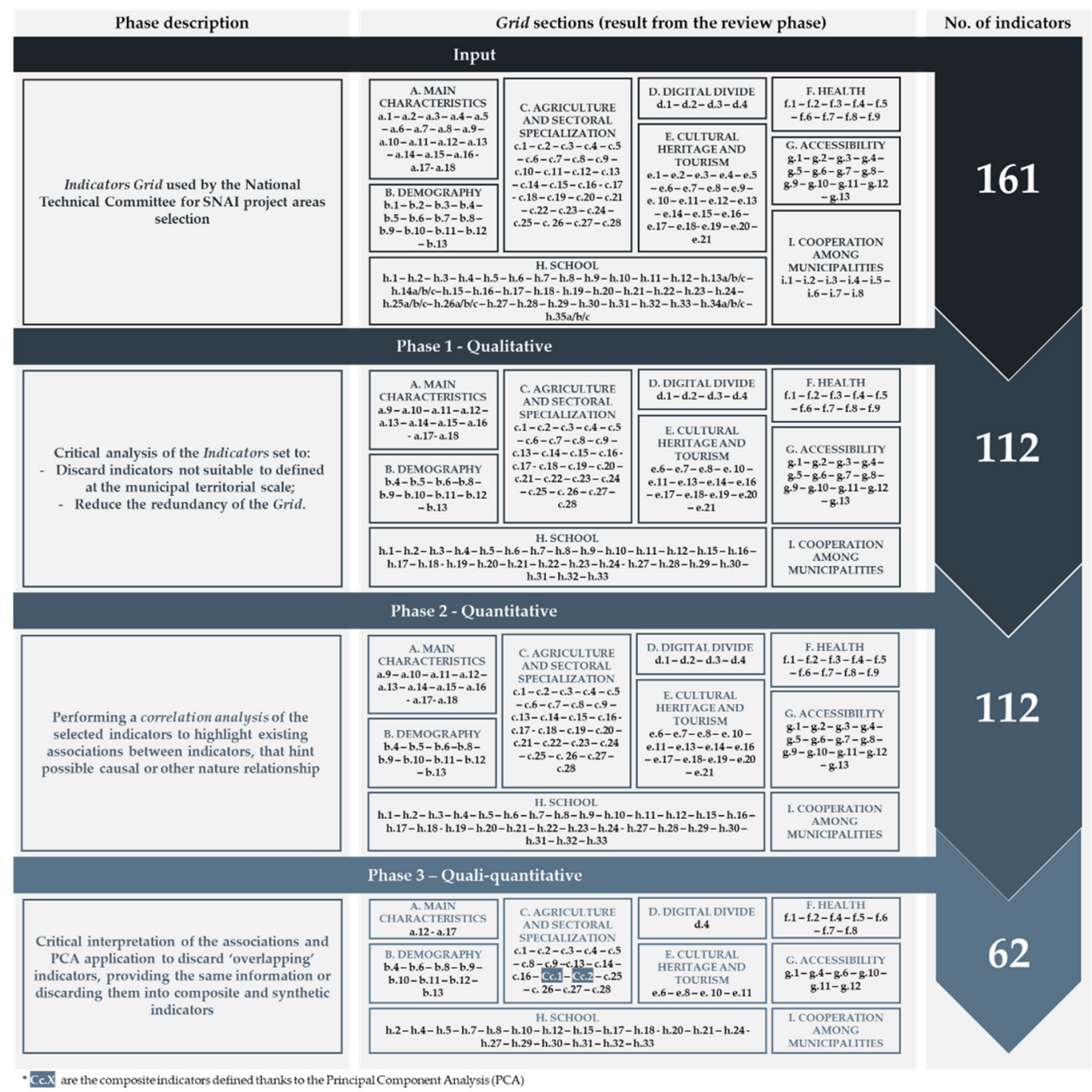

Figure 4. Application of the hybrid methodological approach to the SNAI Indicator Grid (please note, the indicators full list is available in Appendix A).

Table 1. Selected indicators for the "demography" section after critical analysis of the indicator set.

\begin{tabular}{|c|c|c|c|c|c|}
\hline \multicolumn{6}{|c|}{ B. Demography } \\
\hline b. 4 & $\begin{array}{l}\text { Percentage of population } \\
\text { aged } 0-16 \text { in } 2017\end{array}$ & b. 5 & $\begin{array}{l}\text { Percentage of population } \\
\text { aged 17-34 in } 2017\end{array}$ & b. 6 & $\begin{array}{l}\text { Percentage of population } \\
\text { aged } 65+\text { in } 2017\end{array}$ \\
\hline b. 8 & $\begin{array}{l}\text { Percentage of foreign } \\
\text { residents in } 2017\end{array}$ & b. 9 & $\begin{array}{l}\text { Percentage variation in the } \\
\text { resident population } \\
\text { between } 1971 \text { and } 2011\end{array}$ & b.10 & $\begin{array}{l}\text { Percentage variation in the } \\
\text { resident population } \\
\text { between } 2001 \text { and } 2011\end{array}$ \\
\hline b.11 & $\begin{array}{l}\text { Percentage variation in the } \\
\text { resident population } \\
\text { between } 2011 \text { and } 2017\end{array}$ & b.12 & $\begin{array}{l}\text { Percentage variation in the } \\
\text { resident foreign population } \\
\text { between } 2001 \text { and } 2011\end{array}$ & b.13 & $\begin{array}{l}\text { Percentage variation in the } \\
\text { resident foreign } \\
\text { population between } 2011 \\
\text { and } 2017\end{array}$ \\
\hline
\end{tabular}

\subsubsection{Phase 2: Performing a Correlation Analysis of Selected Indicators}

This quantitative phase provides a correlation matrix (Table 2) by displaying the correlation coefficients calculated for each selected indicator couple as a reference point for further considerations towards the Grid's review. 
Table 2. Correlation matrix for the selected indicators in the "demography" section. The background colours in the matrix cells graphically hint the correlation strength.

\begin{tabular}{cccccccccc}
\hline & $\mathbf{b . 4}$ & $\mathbf{b . 5}$ & $\mathbf{b . 6}$ & $\mathbf{b . 8}$ & $\mathbf{b . 9}$ & $\mathbf{b . 1 0}$ & $\mathbf{b . 1 1}$ & $\mathbf{b . 1 2}$ & b.13 \\
\hline $\mathbf{b . 4}$ & 1.000 & & & & & & & & \\
$\mathbf{b . 5}$ & 0.562 & 1.000 & & & & & & & \\
$\mathbf{b . 6}$ & -0.888 & -0.719 & 1.000 & & & & & & \\
$\mathbf{b . 8}$ & -0.201 & -0.260 & 0.315 & 1.000 & & & & & \\
$\mathbf{b . 9}$ & 0.643 & 0.139 & -0.572 & 0.073 & 1.000 & & & & \\
$\mathbf{b . 1 0}$ & 0.508 & -0.084 & -0.367 & 0.371 & 0.872 & 1.000 & & & \\
$\mathbf{b . 1 1}$ & 0.642 & 0.307 & -0.579 & 0.217 & 0.724 & 0.709 & 1.000 & & \\
$\mathbf{b . 1 2}$ & -0.012 & 0.115 & -0.053 & -0.073 & 0.063 & 0.024 & 0.008 & 1.000 & \\
$\mathbf{b . 1 3}$ & 0.234 & 0.566 & -0.351 & -0.438 & -0.104 & -0.323 & 0.198 & 0.199 & 1.000 \\
\hline
\end{tabular}

\subsubsection{Phase 3: Critical Interpretation of the Associations and PCA Application}

This last step aims at completing the review process, starting from the correlation analysis's results interpretation. In particular, the correlation matrix (Table 2) highlights the following:

- $\quad$ B.4 (Percentage of population aged 0-16 in 2017) is moderately correlated with b.5 (Percentage of population aged 17-34 in 2017) and markedly correlated with b.6 (Percentage of population over 65 in 2017); b.5 and b.6 are strongly correlated;

- $\quad$ b.10 (Percentage variation in the resident population between 2001 and 2011) is strongly correlated with b.9 (Percentage variation in the resident population between 1971 and 2011) and markedly correlated with $\mathbf{b . 1 1}$ (Percentage variation in the resident population between 2011 and 2017); at the same time, b.9 and b.11 are markedly correlated.

This section clearly shows the importance of this hybrid methodology's third step, which combines the interpretation of the correlation analysis's results with considerations on the indicators' role in understanding inner areas' dynamics. Indeed, the correlation analysis suggests discarding two indicators among b.9 (Percentage variation in the resident population between 1971 and 2011), b.10 (Percentage variation in the resident population between 2001 and 2011), and b.11 (Percentage variation in the resident population between 2011 and 2017) due to their high correlation. However, delving into their specificities helps to make the right decision. Since these indicators describe the variation in the resident population with different time ranges, they are all useful to understand the shrinking dynamics affecting inner areas and cannot be discarded. On the contrary, it is worth excluding one of the variables among b.4 (Percentage of population aged 0-16 in 2017), b.5 (Percentage of population aged 17-34 in 2017), and b.6 (Percentage of population over 65 in 2017), even if they are only moderately correlated. By completing each other in describing the total resident population age structure, one of these indicators can be deleted without losing any information. Thus, the ultimate choice is to discard the variable b.5. Finally, the "demography" indicators" nature does not suggest applying PCA. Thus, the result of the hybrid methodology is a reviewed "demography" section with only eight indicators (Table 3).

\subsection{The "Agriculture and Sectoral Specialization" Section}

The "agriculture and sectoral specialization" section includes twenty-eight indicators (Table A1) to provide a comprehensive frame of the economic situation in the twenty-two inner areas selected by the SNAI. The application of the three-step hybrid methodology to this section of the Grid, as described below, determines a relevant review. 
Table 3. Reviewed "demography" section in the SNAI Grid.

\begin{tabular}{|c|c|c|c|c|c|}
\hline \multicolumn{6}{|c|}{ B. Demography } \\
\hline b. 4 & $\begin{array}{c}\text { Percentage of } \\
\text { population aged } \\
0-16 \text { in } 2017\end{array}$ & b. 6 & $\begin{array}{l}\text { Percentage of } \\
\text { population aged } 65+ \\
\text { in } 2017\end{array}$ & b. 8 & $\begin{array}{l}\text { Percentage of foreign } \\
\text { residents in } 2017\end{array}$ \\
\hline b.9 & $\begin{array}{l}\text { Percentage variation } \\
\text { in the resident } \\
\text { population between } \\
1971 \text { and } 2011\end{array}$ & b.10 & $\begin{array}{l}\text { Percentage variation } \\
\text { in the resident } \\
\text { population between } \\
2001 \text { and } 2011\end{array}$ & b.11 & $\begin{array}{l}\text { Percentage variation } \\
\text { in the resident } \\
\text { population between } \\
2011 \text { and } 2017\end{array}$ \\
\hline b.12 & $\begin{array}{l}\text { Percentage variation } \\
\text { in the resident } \\
\text { foreign population } \\
\text { between } 2001 \\
\text { and } 2011\end{array}$ & b.13 & $\begin{array}{l}\text { Percentage variation } \\
\text { in the resident } \\
\text { foreign population } \\
\text { between } 2011 \\
\text { and } 2017\end{array}$ & & \\
\hline
\end{tabular}

\subsubsection{Phase 1: Critical Analysis of the Indicator Set}

This first phase, applied to the "agriculture and sectoral specialization" section, allows detecting a low redundancy level due to indicators repeated twice with different time references. However, it is worth reducing the detected redundancy, bringing the number of variables from twenty-eight to twenty-five (Table 4).

Table 4. Selected indicators for the "agriculture and sectoral specialization" section after critical analysis of the indicator set.

\begin{tabular}{|c|c|c|c|c|c|}
\hline \multicolumn{6}{|c|}{ C. Agriculture and Sectoral Specialization } \\
\hline c.1 & $\begin{array}{l}\text { Percentage of utilized } \\
\text { agricultural area (UAA) } \\
\text { in } 2010\end{array}$ & c.2 & $\begin{array}{l}\text { Percentage variation in the } \\
\text { UAA between } 1982 \\
\text { and } 2010\end{array}$ & c.3 & $\begin{array}{l}\text { Percentage variation in the } \\
\text { UAA between } 2000 \\
\text { and } 2010\end{array}$ \\
\hline c. 4 & $\begin{array}{l}\text { Percentage of farmers aged } \\
\text { up to } 39 \text { years on the total of } \\
\text { farmers in } 2010\end{array}$ & c.5 & $\begin{array}{l}\text { Percentage variation in the } \\
\text { number of farmers aged up } \\
\text { to } 39 \text { between } 2000 \text { and } 2010\end{array}$ & c.6 & $\begin{array}{l}\text { Percentage of part-time } \\
\text { farmers in } 2010\end{array}$ \\
\hline c.7 & $\begin{array}{l}\text { Percentage variation in the } \\
\text { number of part-time farmers } \\
\text { between } 2000 \text { and } 2010\end{array}$ & c.8 & Percentage of protected area & c.9 & Percentage of forest area \\
\hline c.13 & $\begin{array}{l}\text { Importance index for the } \\
\text { agricultural sector in } 2011\end{array}$ & c.14 & $\begin{array}{l}\text { Importance index for the } \\
\text { agri-food industry in } 2011\end{array}$ & c.15 & $\begin{array}{l}\text { Importance index for the } \\
\text { total agri-food sector in } 2011\end{array}$ \\
\hline c.16 & $\begin{array}{l}\text { Incidence of farms with } \\
\text { DOP and/or IGP products }\end{array}$ & c.17 & $\begin{array}{l}\text { Breeding farms on the total } \\
\text { of farms }\end{array}$ & c.18 & $\begin{array}{c}\text { Percentage of permanent } \\
\text { meadows and pastors on } \\
\text { the total UAA }\end{array}$ \\
\hline c.19 & Breeding farms' size (UBA) & c.20 & $\begin{array}{c}\text { Percentage of farms with } \\
\text { standard production of } \\
\text { EUR } 25,000\end{array}$ & c.21 & $\begin{array}{l}\text { Specialization index for the } \\
\text { manufacturing sector } \\
\text { in } 2009\end{array}$ \\
\hline c. 22 & $\begin{array}{l}\text { Specialization index for the } \\
\text { energy, gas, and water } \\
\text { sector in } 2009\end{array}$ & c.23 & $\begin{array}{l}\text { Specialization index for the } \\
\text { construction sector in } 2009\end{array}$ & c. 24 & $\begin{array}{l}\text { Specialization index for the } \\
\text { trade sector in } 2009\end{array}$ \\
\hline c.25 & $\begin{array}{l}\text { Specialization index for the } \\
\text { other services sector in } 2009\end{array}$ & c.26 & $\begin{array}{c}\text { Number of companies per } \\
1000 \text { inhabitants }\end{array}$ & c.27 & $\begin{array}{c}\text { Companies' stock growth } \\
\text { rate in } 2013\end{array}$ \\
\hline c. 28 & $\begin{array}{l}\text { Percentage of } \\
\text { foreign companies }\end{array}$ & & & & \\
\hline
\end{tabular}

4.2.2. Phase 2: Performing a Correlation Analysis of Selected Indicators

This step provides a correlation matrix, displaying all the correlation coefficients for each pair of selected indicators (Table 5). 
Table 5. Correlation matrix for the selected indicators in the "agricultural and sectoral specialization" section.

\begin{tabular}{|c|c|c|c|c|c|c|c|c|c|c|c|c|c|c|c|c|c|c|c|c|c|c|c|c|c|}
\hline & c.1 & c. 2 & c. 3 & c. 4 & c.5 & c. 6 & c.7 & c. 8 & c. 9 & c.13 & c.14 & c.15 & c.16 & c.17 & c.18 & c.19 & c. 20 & c. 21 & c. 22 & c.23 & c. 24 & c. 25 & c.26 & c.27 & c. 28 \\
\hline c.1 & 1.00 & & & & & & & & & & & & & & & & & & & & & & & & \\
\hline c. 2 & 0.84 & 1.00 & & & & & & & & & & & & & & & & & & & & & & & \\
\hline c. 3 & 0.63 & 0.74 & 1.00 & & & & & & & & & & & & & & & & & & & & & & \\
\hline c.4 & -0.39 & -0.29 & -0.22 & 1.00 & & & & & & & & & & & & & & & & & & & & & \\
\hline c.5 & -0.10 & -0.08 & 0.13 & 0.59 & 1.00 & & & & & & & & & & & & & & & & & & & & \\
\hline c. 6 & -0.02 & 0.08 & 0.01 & 0.26 & 0.15 & 1.00 & & & & & & & & & & & & & & & & & & & \\
\hline c.7 & -0.18 & -0.16 & -0.20 & 0.41 & 0.56 & 0.25 & 1.00 & & & & & & & & & & & & & & & & & & \\
\hline c. 8 & 0.11 & 0.24 & 0.24 & -0.22 & 0.00 & 0.18 & 0.07 & 1.00 & & & & & & & & & & & & & & & & & \\
\hline c. 9 & -0.69 & -0.51 & -0.37 & 0.18 & -0.05 & -0.13 & -0.14 & -0.04 & 1.00 & & & & & & & & & & & & & & & & \\
\hline c.13 & 0.37 & 0.22 & 0.14 & -0.20 & 0.06 & -0.24 & -0.08 & 0.04 & -0.09 & 1.00 & & & & & & & & & & & & & & & \\
\hline c.14 & -0.20 & -0.25 & -0.30 & 0.04 & -0.10 & 0.09 & 0.26 & 0.01 & 0.11 & -0.06 & 1.00 & & & & & & & & & & & & & & \\
\hline c.15 & 0.26 & 0.10 & 0.00 & -0.16 & 0.01 & -0.18 & 0.03 & 0.04 & -0.03 & 0.91 & 0.35 & 1.00 & & & & & & & & & & & & & \\
\hline c.16 & -0.27 & -0.26 & -0.28 & 0.24 & -0.01 & -0.10 & -0.07 & -0.11 & 0.12 & 0.29 & 0.09 & 0.32 & 1.00 & & & & & & & & & & & & \\
\hline c.17 & -0.65 & -0.52 & -0.42 & 0.64 & 0.22 & 0.01 & 0.32 & -0.15 & 0.39 & -0.42 & 0.18 & -0.32 & 0.19 & 1.00 & & & & & & & & & & & \\
\hline c. 18 & -0.64 & -0.39 & -0.25 & 0.50 & 0.16 & 0.08 & 0.14 & 0.13 & 0.50 & -0.36 & 0.05 & -0.31 & 0.09 & 0.79 & 1.00 & & & & & & & & & & \\
\hline c.19 & 0.38 & 0.34 & 0.18 & -0.15 & -0.16 & -0.03 & 0.11 & -0.03 & -0.45 & 0.03 & 0.20 & 0.11 & -0.03 & -0.25 & -0.38 & 1.00 & & & & & & & & & \\
\hline c. 20 & -0.08 & -0.03 & -0.07 & 0.40 & 0.02 & -0.13 & 0.04 & -0.26 & -0.03 & -0.01 & 0.13 & 0.04 & 0.48 & 0.37 & 0.08 & 0.44 & 1.00 & & & & & & & & \\
\hline c. 21 & -0.10 & -0.09 & -0.17 & -0.03 & -0.13 & -0.01 & 0.18 & -0.29 & 0.14 & -0.13 & 0.12 & -0.08 & -0.12 & 0.14 & -0.11 & 0.06 & 0.16 & 1.00 & & & & & & & \\
\hline c. 22 & 0.32 & 0.27 & 0.16 & -0.20 & -0.17 & -0.01 & -0.04 & 0.09 & -0.21 & 0.09 & 0.19 & 0.16 & -0.21 & -0.16 & -0.17 & 0.28 & -0.03 & -0.13 & 1.00 & & & & & & \\
\hline c. 23 & 0.00 & 0.01 & 0.02 & -0.05 & 0.06 & -0.26 & -0.13 & 0.11 & 0.23 & 0.17 & 0.04 & 0.18 & -0.04 & -0.09 & 0.05 & -0.11 & -0.13 & -0.36 & 0.12 & 1.00 & & & & & \\
\hline c. 24 & 0.51 & 0.37 & 0.42 & -0.24 & -0.02 & -0.01 & -0.41 & 0.15 & -0.22 & 0.21 & -0.28 & 0.08 & -0.26 & -0.57 & -0.34 & 0.04 & -0.30 & -0.62 & 0.13 & 0.18 & 1.00 & & & & \\
\hline c. 25 & -0.27 & -0.19 & -0.10 & 0.25 & 0.17 & 0.12 & 0.09 & 0.19 & -0.08 & -0.07 & -0.03 & -0.07 & 0.40 & 0.26 & 0.37 & -0.11 & 0.07 & -0.70 & -0.14 & -0.16 & 0.03 & 1.00 & & & \\
\hline c. 26 & 0.25 & 0.18 & -0.11 & -0.10 & -0.19 & -0.20 & 0.05 & -0.04 & -0.24 & 0.49 & -0.01 & 0.46 & 0.45 & -0.23 & -0.40 & 0.35 & 0.26 & 0.10 & 0.04 & -0.07 & -0.16 & 0.01 & 1.00 & & \\
\hline c. 28 & -0.24 & -0.23 & -0.22 & -0.22 & -0.18 & -0.18 & -0.10 & -0.05 & 0.28 & -0.16 & 0.06 & -0.13 & -0.06 & -0.09 & -0.01 & -0.21 & -0.25 & 0.18 & -0.21 & 0.10 & -0.07 & -0.19 & -0.08 & -0.03 & 1.00 \\
\hline
\end{tabular}




\subsubsection{Phase 3: Critical Interpretation of the Associations and PCA Application}

As already seen for the "demography" section, this last phase towards the Grid's review moves to the correlation analysis results interpretation (Table 5). In particular, looking at the correlation matrix, it is possible to state that indicators from the "agriculture and sectoral specialization" section are not highly correlated among them, with some exceptions:

- $\quad$ c.1 (Percentage of UAA in 2010) and c.2 (Percentage variation in the UAA between 1982 and 2010) are strongly correlated, and they are both markedly correlated with c.3 (Percentage variation in the UAA between 2000 and 2010);

- $\quad$ c.15 (Percentage of UAA in 2010) and c.13 (Percentage variation in the UAA between 1982 and 2010) are strongly correlated.

This finding of the low association among variables led to assign the indicators contribution in catching and explaining inner areas' dynamics with a primary role in this section's review.

In this light, it is appropriate to discard indicators c.6 (Percentage of part-time farmers in 2010) and c.7 (Percentage variation in the number of part-time farmers between 2000 and 2010), since they merely detail a phenomenon already captured by other indicators in the Grid. The same reasoning explains discarding indicators c.17 (Breeding farms on the total of farms), c.18 (Percentage of permanent meadows and pastors on the total UAA), c.19 (Breeding farms' size), c.20 (Percentage of farms with standard production of EUR 25,000). Indeed, these variables provide detailed information about the farming phenomenon, already described by other indicators in the section, that better fits the Grid's nature as a general investigation and understanding support tool.

Furthermore, the presence of an underlying dimension, shared by the "sector specialization" indicators-c.21, c.22, c.23, c.24, and c.25-together with their decent correlation, calls for principal component analysis's application to combine them into fewer composite indicators.

The starting point for the PCA is the correlation matrix for the considered indicators (Table 6).

Table 6. Correlation matrix for the sectoral specialization indicators c.21, c.22, c.23, c.24, and c.25.

\begin{tabular}{cccccc}
\hline & $\mathbf{c 2 1}$ & $\mathbf{c 2 2}$ & $\mathbf{c 2 3}$ & $\mathbf{c 2 4}$ & $\mathbf{c 2 5}$ \\
\hline $\mathbf{c 2 1}$ & 1.000 & -0.126 & -0.364 & -0.616 & -0.696 \\
$\mathbf{c 2 2}$ & -0.126 & 1.000 & 0.125 & 0.132 & -0.141 \\
$\mathbf{c 2 3}$ & -0.364 & 0.125 & 1.000 & 0.182 & -0.159 \\
$\mathbf{c 2 4}$ & -0.616 & 0.132 & 0.182 & 1.000 & 0.030 \\
$\mathbf{c 2 5}$ & -0.696 & -0.141 & -0.159 & 0.030 & 1.000 \\
\hline
\end{tabular}

Based on it, indeed, it is possible to determine the eigenvalues (Table 7), by describing the variance of each principal component and the related eigenvectors (Table 8) and, subsequently, by representing the loading factors to transform the original indicators into their principal components.

Table 7. Eigenvalues matrix related to the correlation matrix.

\begin{tabular}{c|cccc}
\hline 2.0320 & 0 & 0 & 0 & 0 \\
0 & 1.33833 & 0 & 0 & 0 \\
0 & 0 & 0.878154 & 0 & 0 \\
0 & 0 & 0 & 0.748434 & 0 \\
0 & 0 & 0 & 0 & 0.00313 \\
\hline
\end{tabular}


Table 8. Eigenvectors matrix related to the correlation matrix.

\begin{tabular}{ccccc}
\hline $\mathbf{e 1}$ & $\mathbf{e 2}$ & $\mathbf{e 3}$ & $\mathbf{e 4}$ & $\mathbf{e 5}$ \\
\hline-1.6432 & -0.1513 & 0.0212 & -0.2564 & 1.3153 \\
0.2946 & -0.8150 & 4.8531 & 0.9022 & 0.1566 \\
0.6676 & -0.8198 & -3.6169 & 1.4747 & 0.4975 \\
1.1664 & -0.3953 & 0.0171 & -2.2907 & 0.6713 \\
1 & 1 & 1 & 1 & 1 \\
\hline
\end{tabular}

Thus, differently from other existing stopping rules, the Kaiser criterion is applied to identify the number of principal components to be retained as composite indicators of the original ones, explaining most of their variance. According to this criterion, which suggests dropping all principal components with an eigenvalue less than 1, it is worth considering only the first two principal components. Indeed, only the first two eigenvalues are valued more than 1 (Table 9).

Table 9. Eigenvalues and related numerical values.

\begin{tabular}{llc}
\hline$\lambda_{1}$ & 2.0320 \\
$\lambda_{2}$ & 1.3383 \\
$\lambda_{3}$ & 0.87815 \\
$\lambda_{4}$ & 0.74843 \\
$\lambda_{5}$ & 0.00313 \\
\hline
\end{tabular}

In this light, the original five indicators can be composed and described through their first two principal components, thus further rationalizing the "agriculture and sectoral specialization" section in the SNAI Grid. In particular, by considering the loading factors provided by the related eigenvectors, the so-defined principal components can be calculated through the following formulas:

$$
\begin{gathered}
\mathrm{Cc} 1=-1.64235(\mathrm{c} 21)+0.29463(\mathrm{c} 22)+0.66767(\mathrm{c} 23)+1.664(\mathrm{c} 24)+1(\mathrm{c} 25), \\
\mathrm{Cc} 2=-0.15130(\mathrm{c} 21)-0.81501(\mathrm{c} 22)-0.81983(\mathrm{c} 23)-0.3953(\mathrm{c} 24)+1(\mathrm{c} 25),
\end{gathered}
$$

Therefore, by crossing the results from the critical interpretation of the associations among indicators and the PCA, the last step in the hybrid methodology provides a significant review of the "agriculture and sectoral specialization" sector in the Grid by reducing the indicators' number from twenty-eight to eighteen (Table 10).

\begin{tabular}{|c|c|c|c|c|c|}
\hline \multicolumn{6}{|c|}{ C. Agriculture and Sectoral Specialization } \\
\hline c.1 & $\begin{array}{l}\text { Percentage of utilized agricultural } \\
\text { area (UAA) in } 2010\end{array}$ & c. 2 & $\begin{array}{l}\text { Percentage variation in the } \\
\text { UAA between } 1982 \text { and } 2010\end{array}$ & c.3 & $\begin{array}{l}\text { Percentage variation in the } \\
\text { UAA between } 2000 \text { and } 2010\end{array}$ \\
\hline c. 4 & $\begin{array}{l}\text { Percentage of farmers aged up to } 39 \\
\text { years on the total of farmers in } 2010\end{array}$ & c.5 & $\begin{array}{l}\text { Percentage variation in the } \\
\text { number of farmers aged up to } \\
39 \text { between } 2000 \text { and } 2010\end{array}$ & c.8 & Percentage of protected area \\
\hline c.9 & Percentage of forest area & c.13 & $\begin{array}{l}\text { Importance index for the } \\
\text { agricultural sector in } 2011\end{array}$ & c.14 & $\begin{array}{l}\text { Importance index for the } \\
\text { agri-food industry in } 2011\end{array}$ \\
\hline c.16 & $\begin{array}{l}\text { Incidence of farms with DOP } \\
\text { and/or IGP products }\end{array}$ & Cc.1 & $\begin{array}{l}\text { Specialization composite } \\
\text { index (trade and } \\
\text { manufacturing) }\end{array}$ & Cc.2 & $\begin{array}{l}\text { Specialization composite } \\
\text { index (construction and } \\
\text { energy supply) }\end{array}$ \\
\hline c. 25 & $\begin{array}{l}\text { Specialization index for the other } \\
\text { services sector in } 2009\end{array}$ & c.26 & $\begin{array}{c}\text { Number of companies per } \\
1000 \text { inhabitants }\end{array}$ & c.27 & $\begin{array}{c}\text { Companies' stock growth rate } \\
\text { in } 2013\end{array}$ \\
\hline c. 28 & Percentage of foreign companies & & & & \\
\hline
\end{tabular}

Table 10. Reviewed "agriculture and sectoral specialization" section of the SNAI Grid. 


\subsection{The "Cultural Heritage and Tourism" Section}

The "cultural heritage and tourism" section comprises twenty-one indicators (Table A1) to provide information about cultural heritage and the touristic phenomenon's relevance in the seventy-two project areas. The proposed hybrid methodology applied to this section of the Grid provides its consistent review, as explained below.

\subsubsection{Phase 1: Critical Analysis of the Indicator Set}

Critical analysis of the indicator set related to the "cultural heritage and tourism section" does not return the presence of unsuitable indicators for the municipality scale. On the contrary, it highlights a high redundancy level due to many indicators repeated twice with different time horizons. For this reason, a first review in the variable set, geared towards reducing its redundancy, is performed, bringing the number of indicators from twenty-one to thirteen (Table 11).

Table 11. Selected indicators for the "cultural heritage and tourism" section after critical analysis of the indicator set.

\begin{tabular}{|c|c|c|c|c|c|}
\hline \multicolumn{6}{|c|}{ E. Cultural Heritage and Tourism } \\
\hline e.6 & $\begin{array}{c}\text { Number of state and non-state } \\
\text { cultural sites in } 2015\end{array}$ & e.7 & Number of visitors in 2015 & e.8 & $\begin{array}{l}\text { Number of visitors per } 1000 \\
\text { inhabitants in } 2015\end{array}$ \\
\hline e.10 & $\begin{array}{l}\text { Accommodation rate-bed places } \\
\text { for } 1000 \text { inhabitants in } 2016\end{array}$ & e.11 & $\begin{array}{c}\text { Tourism rate-number of } \\
\text { presences per } 1000 \text { inhabitants } \\
\text { in } 2016\end{array}$ & e.13 & Arrivals in 2016 \\
\hline e.14 & $\begin{array}{l}\text { Percentage variation in arrivals } \\
\text { between } 2014 \text { and } 2016\end{array}$ & e.16 & Presences in 2016 & e.17 & $\begin{array}{c}\text { Percentage variation in presences } \\
\text { between } 2014 \text { and } 2016\end{array}$ \\
\hline e.18 & $\begin{array}{l}\text { Percentage of presences in hotel } \\
\text { facilities in } 2016\end{array}$ & e.19 & $\begin{array}{l}\text { Percentage of presences in } \\
\text { extra-hotel facilities in } 2016\end{array}$ & e.20 & $\begin{array}{l}\text { Percentage of arrivals in hotel } \\
\text { facilities in } 2016\end{array}$ \\
\hline e.21 & $\begin{array}{l}\text { Percentage of arrivals in } \\
\text { extra-hotel facilities in } 2016\end{array}$ & & & & \\
\hline
\end{tabular}

\subsubsection{Phase 2: Performing a Correlation Analysis of Selected Indicators}

This step highlights the indicator pairs to focus on because of their association by performing correlation analysis. Based on this premise, correlation coefficients for each variable couple are calculated and displayed in a correlation matrix (Table 12).

Table 12. Correlation matrix for the selected indicators in the "cultural heritage and tourism" section.

\begin{tabular}{|c|c|c|c|c|c|c|c|c|c|c|c|c|c|}
\hline & e.6 & e. 7 & e. 8 & e.10 & e.11 & e.13 & e.14 & e.16 & e.17 & e.18 & e.19 & e. 20 & e. 21 \\
\hline e.6 & 1.000 & & & & & & & & & & & & \\
\hline e. 7 & 0.402 & 1.000 & & & & & & & & & & & \\
\hline e. 8 & 0.482 & 0.848 & 1.000 & & & & & & & & & & \\
\hline e.10 & 0.160 & -0.035 & 0.214 & 1.000 & & & & & & & & & \\
\hline e.11 & 0.064 & -0.021 & 0.193 & 0.925 & 1.000 & & & & & & & & \\
\hline e.13 & -0.009 & 0.101 & 0.265 & 0.592 & 0.768 & 1.000 & & & & & & & \\
\hline e.14 & -0.172 & 0.063 & 0.120 & 0.014 & 0.007 & -0.023 & 1.000 & & & & & & \\
\hline e.16 & -0.089 & 0.045 & 0.160 & 0.507 & 0.708 & 0.943 & -0.020 & 1.000 & & & & & \\
\hline e.17 & -0.197 & 0.002 & 0.057 & 0.012 & 0.015 & -0.013 & 0.830 & -0.010 & 1.000 & & & & \\
\hline e.18 & -0.207 & 0.239 & 0.177 & 0.080 & 0.171 & 0.179 & -0.186 & 0.097 & -0.074 & 1.000 & & & \\
\hline e.19 & 0.207 & -0.239 & -0.177 & -0.080 & -0.171 & -0.179 & 0.186 & -0.097 & 0.074 & -1.000 & 1.000 & & \\
\hline e. 20 & -0.299 & 0.186 & 0.118 & 0.083 & 0.166 & 0.230 & -0.148 & 0.153 & -0.056 & 0.946 & -0.946 & 1.000 & \\
\hline e. 21 & 0.299 & -0.186 & -0.118 & -0.083 & -0.166 & -0.230 & 0.148 & -0.153 & 0.056 & -0.946 & 0.946 & -1.000 & 1.000 \\
\hline
\end{tabular}

\subsubsection{Phase 3: Critical Interpretation of the Associations and PCA Application}

This last step aims at further rationalizing the SNAI Grid, moving to the correlation analysis results. In particular, the correlation matrix (Table 12) shows the following:

- $\quad$ e.7 (Number of visitors in 2015) and e.8 (Number of visitors per 1000 inhabitants in 2015) are strongly correlated; 
- $\quad \mathbf{e . 1 1}$ (Tourism rate-number of presences per 1000 inhabitants in 2016) is strongly correlated with e.10 (Accommodation rate-bed places for 1000 inhabitants in 2016) and markedly correlated both with e.13 (Arrivals in 2016) and e.16 (Presences in 2016);

- $\quad$ e.16 (Presences in 2016) is strongly correlated with e.13 (Arrivals in 2016);

- $\quad$ e.17 (Percentage variation in presences between 2014 and 2016) is strongly correlated with e.14 (Percentage variation in arrivals between 2014 and 2016);

- $\quad \mathbf{e . 1 8}$ (Percentage of presences in hotel facilities in 2016), e.19 (Percentage of presences in extra-hotel facilities in 2016), e.20 (Percentage of arrivals in hotel facilities in 2016), and e.21 (Percentage of arrivals in extra-hotel facilities in 2016) are strongly correlated with each other.

Thus, by combining this information with an in-depth reflection on the indicators' contribution in understanding inner areas' dynamics, it is possible to discard other indicators. For instance, as mentioned, the indicators e.7 (Number of visitors in 2015) and e.8 (Number of visitors per 1000 inhabitants in 2015) are strongly correlated, with a Pearson coefficient equal to 0.848 . This result is easily predictable since indicator e.8's calculation is based on e.7. However, to assess the opportunity to discard one of them, this quantitative step is not enough. Still, it becomes crucial to critically consider the variables' capacity of describing a specific phenomenon in the inner areas' context.

In particular, concerning the two mentioned indicators, they both describe the attractiveness of cultural sites in the considered territorial context, but e.8 adds another information layer related to the impact of this attractiveness on the resident population. Thus, it is justifiable to discard indicator e.7 without shrinking the Grid's complexity and information level.

While approaching with the same critical eye and thinking of the other indicators, the "cultural heritage and tourism" section is drastically rationalized, coming to a set of four variables (Table 13).

Table 13. Reviewed "cultural heritage and tourism" section of the SNAI Grid.

\begin{tabular}{cccccc}
\hline \multicolumn{5}{c}{ E. Cultural Heritage and Tourism } & \\
\hline e.6 & $\begin{array}{c}\text { Number of state and non-state } \\
\text { cultural sites in 2015 }\end{array}$ & e.8 & $\begin{array}{c}\text { Number of visitors per 1000 } \\
\text { inhabitants in 2015 }\end{array}$ & e.10 & $\begin{array}{c}\text { Accommodation rate-bed places } \\
\text { for 1000 inhabitants in 2016 }\end{array}$ \\
e.11 & $\begin{array}{c}\text { Tourism rate-number of presences } \\
\text { per 1000 inhabitants in 2016 }\end{array}$ & & & \\
\hline
\end{tabular}

\subsection{The "Cooperation among Municipalities" Section}

The "cooperation among municipalities" section contains eight indicators (Table A1) describing the propensity towards cooperation within each project area. In this case, the hybrid methodology towards the Grid's review ends with the first step, discarding all the indicators. Indeed, differently from the other sections, critical analysis of the indicator set does not highlight redundancy but, rather, the unsuitability of the existing variables to be applied at the municipality scale. However, given the importance of creating local synergies among and within municipalities for fragile areas [44], the Grid cannot be exempt from covering this phenomenon. The special need to address this issue is discussed in the Results and Discussion section.

\section{Results, Discussion, and Further Developments}

The hybrid methodology's application allows the SNAI Indicator Grid's review by reducing its number of indicators from 161 to 62 without losing its information and complexity level.

The so-obtained parsimonious Grid can stand as a helpful tool according to SNAI instances by supporting decision-makers in public and private spheres in the following ways: 
- Gaining a comprehensive understanding of territorial dynamics and power balances thanks to the data related to each Grid section and available for each municipality within each inner area;

- Defining interventions and efficiently allocating resources according to the actual inner areas' needs;

- Prioritizing actions within a project area or selecting additional areas for SNAI relaunch;

- Providing a good reference for setting goals to be reached and for their monitoring in performance terms.

Furthermore, the Grid variables and their correlation can represent valuable support for spatial interpretation of relationships between depopulation, economic dynamics, and the effects from SNAI and other public policies dealing with inner areas [45,46].

In this sense, a significant advantage can stem from integrating the indicator set in a GIS environment; this integration can provide a graphical representation of the indicators' values for each municipality and allow an easier comprehension of the different territorial dynamics [47-49] (Figure 5).

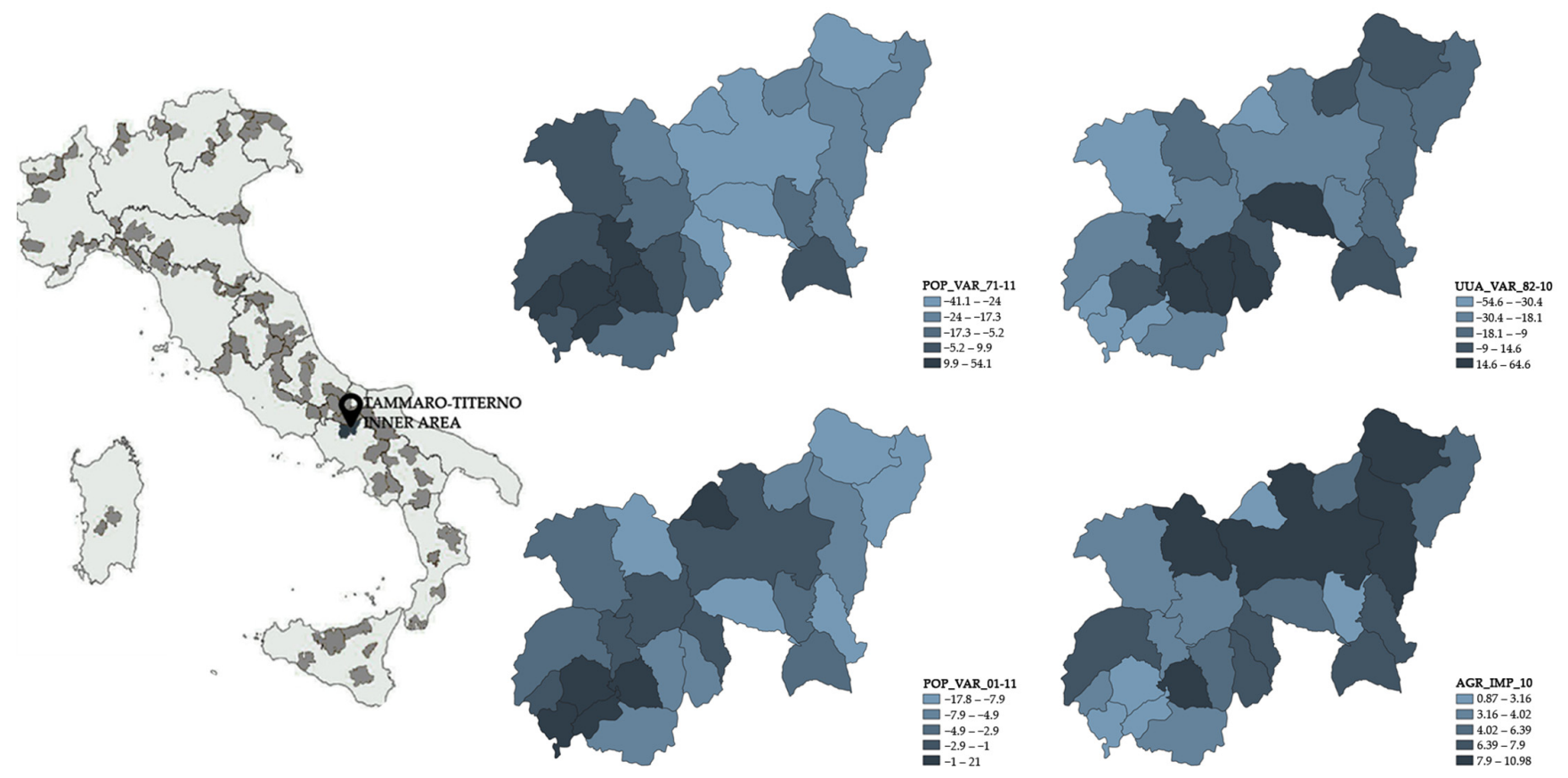

Figure 5. Graphical representation of some indicators' values for municipalities belonging to one of the 72 SNAI project areas: Tammaro-Titerno inner area in Campania region.

Again, in defining priorities for actions, the multi-dimensional nature of the SNAI Grid well fits its integration with an MCDA approach, aimed at drawing out a ranking of municipalities according to specific needs or potentialities and coherently with different stakeholders' expectations [50-52].

However, the parsimonious Grid is still endowed with some criticalities to be overcome. When dealing with some of the Grid's sections, especially the cultural heritage and tourism section, the existing indicators' inadequacy to provide a complete picture of cultural heritage in inner areas becomes evident, both in its tangible and intangible elements [53]. For this reason, a further effort should be devoted to defining other indicators, different from the ones proposed by the SNAI Grid, representing cultural heritage physical characteristics, its conditions of use, and the presence of enhancement strategies. Furthermore, the same opportunity emerges when addressing the cooperation among municipalities section. Here, indeed, the need to define all indicators at the municipality scale led to discarding all the variables in the original SNAI Grid. Thus, new indicators must be defined, considering, 
together with municipalities' cooperation, the importance of capturing third sector entities' and citizens associations' roles [54] for establishing place-based approaches [55]. Finally, while preserving its nature of a neutral and general framework, applicable to different realities, the Grid should host some more indicators to better describe local features since they include most of the inner areas' potential for innovation in economic, social, and cultural terms.

The highlighted local specificities' importance opens up a last relevant point regarding the parsimonious Grid's application as a decision support tool. Despite its importance as an objective and multi-dimensional reference for decisions about inner areas, indeed, the Grid is not enough to guide decision-makers towards informed and context-aware choices. In this sense, it becomes necessary to integrate the Grid data with values stemming from the interaction with local communities and their related complex systems of interests at stake [56-58]. With this aim, an application to a real case study, represented by one of the Italian inner areas, will be helpful in testing and implementing the Grid integration with a value-based approach, thus contributing to framing it as an effective decision support tool for decision making.

Author Contributions: Conceptualization, M.R., M.D., A.O. and F.T.; methodology, M.R. and F.T.; software, M.R. and M.D.; validation, A.O. and F.T.; formal analysis, A.O. and F.T.; data curation, M.R.; writing—original draft preparation, M.R. and M.D.; writing—review and editing, M.R., M.D., A.O. and F.T.; visualization, M.R. All authors have read and agreed to the published version of the manuscript.

Funding: This research was supported by the DAStU “Fragilità Territoriali" Research Project, funded by the Italian Ministry of Education, Universities, and Research (MIUR), Departments of Excellence Initiative 2018-2022.

Data Availability Statement: The analyses conducted within this study are based on official data, available at http:/ / old2018.agenziacoesione.gov.it/it/arint/OpenAreeInterne/index.html (accessed on 18 March 2021).

Conflicts of Interest: The authors declare no conflict of interest.

\section{Appendix A}

Table A1 displays the complete list of the indicators composing the SNAI Indicator Grid: in the table, the ones to be kept in its "rationalized version" proposed by this study are highlighted, together with the two composite indicators obtained through the PCA application.

Table A1. Complete list of SNAI Grid's indicators, highlighting the ones to be kept in its "parsimonious version".

\begin{tabular}{|c|c|c|c|c|c|}
\hline \multicolumn{6}{|c|}{ A. Main Characteristics } \\
\hline a.1 & Number of municipalities in 2011 & a.2 & of which: inner areas & a.3 & $\begin{array}{l}\text { of which: peripheral and } \\
\text { ultra-peripheral areas }\end{array}$ \\
\hline a.4 & Resident population in 2011 & a.5 & of which: inner areas & a.6 & $\begin{array}{l}\text { of which: peripheral and } \\
\text { ultra-peripheral areas }\end{array}$ \\
\hline a.7 & of which: percentage inner areas & a.8 & $\begin{array}{c}\text { of which: percentage peripheral } \\
\text { and ultra-peripheral } \\
\text { areas }\end{array}$ & a.9 & Number of municipalities in 2017 \\
\hline a.10 & of which: inner areas & a.11 & $\begin{array}{l}\text { of which: peripheral and } \\
\text { ultra-peripheral areas }\end{array}$ & a.12 & Resident population in 2017 \\
\hline a.13 & of which: inner areas & a.14 & $\begin{array}{l}\text { of which: peripheral and } \\
\text { ultra-peripheral areas }\end{array}$ & a.15 & of which: percentage inner areas \\
\hline a.16 & $\begin{array}{c}\text { of which: percentage peripheral and } \\
\text { ultra-peripheral } \\
\text { areas }\end{array}$ & a.17 & Total area in $\mathrm{km}^{2}$ & a.18 & Density per $\mathrm{km}^{2}$ \\
\hline
\end{tabular}


Table A1. Cont.

\begin{tabular}{|c|c|c|c|c|c|}
\hline \multicolumn{6}{|c|}{ B. Demography } \\
\hline b.1 & $\begin{array}{l}\text { Percentage of population aged } 0-16 \text { in } \\
\qquad 2011\end{array}$ & b. 2 & $\begin{array}{l}\text { Percentage of population aged } \\
\qquad 17-34 \text { in } 2011\end{array}$ & b. 3 & $\begin{array}{l}\text { Percentage of population aged } \\
\qquad 65+\text { in } 2011\end{array}$ \\
\hline b.4 & $\begin{array}{l}\text { Percentage of population aged } 0-16 \text { in } \\
\qquad 2017\end{array}$ & b. 5 & $\begin{array}{l}\text { Percentage of population aged } \\
\qquad 17-34 \text { in } 2017\end{array}$ & b.6 & $\begin{array}{l}\text { Percentage of population aged } \\
665+\text { in } 2017\end{array}$ \\
\hline b.7 & Percentage of foreign residents in 2011 & b.8 & $\begin{array}{l}\text { Percentage of foreign residents } \\
\text { in } 2017\end{array}$ & b.9 & $\begin{array}{l}\text { Percentage variation in the } \\
\text { resident population between } 1971 \\
\text { and } 2011\end{array}$ \\
\hline b.10 & $\begin{array}{l}\text { Percentage variation in the resident } \\
\text { population between } 2001 \text { and } 2011\end{array}$ & b.11 & $\begin{array}{l}\text { Percentage variation in the } \\
\text { resident population between } \\
2011 \text { and } 2017\end{array}$ & b.12 & $\begin{array}{l}\text { Percentage variation in the } \\
\text { resident foreign population } \\
\text { between } 2001 \text { and } 2011\end{array}$ \\
\hline b.13 & $\begin{array}{l}\text { Percentage variation in the resident } \\
\text { foreign population between } 2011 \text { and } \\
2017\end{array}$ & & & & \\
\hline \multicolumn{6}{|c|}{ C. Agriculture and Sectoral Specialization } \\
\hline c.1 & $\begin{array}{l}\text { Percentage of utilized agricultural area } \\
\text { (UAA) in } 2010\end{array}$ & c. 2 & $\begin{array}{l}\text { Percentage variation in the } \\
\text { UAA between } 1982 \text { and } 2010\end{array}$ & c.3 & $\begin{array}{l}\text { Percentage variation in the UAA } \\
\text { between } 2000 \text { and } 2010\end{array}$ \\
\hline c.4 & $\begin{array}{l}\text { Percentage of farmers aged up to } 39 \\
\text { years on the total of farmers in } 2010\end{array}$ & c.5 & $\begin{array}{l}\text { Percentage variation in the } \\
\text { number of farmers aged up to } \\
39 \text { between } 2000 \text { and } 2010\end{array}$ & c.6 & $\begin{array}{l}\text { Percentage of part-time farmers in } \\
\qquad 2010\end{array}$ \\
\hline c.7 & $\begin{array}{l}\text { Percentage variation in the number of } \\
\text { part-time farmers between } 2000 \text { and } \\
2010\end{array}$ & c. 8 & Percentage of protected area & c.9 & Percentage of forest area \\
\hline c.10 & $\begin{array}{l}\text { Importance index for the agricultural } \\
\text { sector in } 2001\end{array}$ & c.11 & $\begin{array}{l}\text { Importance index for the } \\
\text { agri-food industry in } 2001\end{array}$ & c.12 & $\begin{array}{l}\text { Importance index for the total } \\
\text { agri-food sector in } 2001\end{array}$ \\
\hline c.13 & $\begin{array}{l}\text { Importance index for the agricultural } \\
\text { sector in } 2011\end{array}$ & c.14 & $\begin{array}{l}\text { Importance index for the } \\
\text { agri-food industry in } 2011\end{array}$ & c.15 & $\begin{array}{l}\text { Importance index for the total } \\
\text { agri-food sector in } 2011\end{array}$ \\
\hline c.16 & $\begin{array}{l}\text { Incidence of farms with DOP and/or } \\
\text { IGP products }\end{array}$ & c.17 & \multirow{2}{*}{$\begin{array}{l}\text { Breeding farms on the total of } \\
\text { farms } \\
\text { Percentage of farms with } \\
\text { standard production of } \\
\text { EUR } 25,000\end{array}$} & c.18 & $\begin{array}{c}\text { Percentage of permanent } \\
\text { meadows and pastors on the total } \\
\text { UAA }\end{array}$ \\
\hline c.19 & Breeding farms size (UBA) & c.20 & & c.21 & $\begin{array}{l}\text { Specialization index for the } \\
\text { manufacturing sector in } 2009\end{array}$ \\
\hline c. 22 & \multirow{2}{*}{$\begin{array}{l}\text { Specialization index for the energy, gas, } \\
\text { and water sector in } 2009 \\
\text { Specialization index for the other } \\
\text { services sector in } 2009\end{array}$} & c. 23 & $\begin{array}{l}\text { Specialization index for the } \\
\text { construction sector in } 2009\end{array}$ & c. 24 & $\begin{array}{l}\text { Specialization index for the trade } \\
\text { sector in } 2009\end{array}$ \\
\hline c. 25 & & c.26 & $\begin{array}{l}\text { Number of companies per } 1000 \\
\text { inhabitants }\end{array}$ & c.27 & $\begin{array}{l}\text { Companies' stock growth rate in } \\
2013\end{array}$ \\
\hline c. 28 & Percentage of foreign companies & & & & \\
\hline \multicolumn{6}{|c|}{ D. Digital Divide } \\
\hline d.1 & $\begin{array}{l}\text { Percentage of population reached by } \\
\text { fixed-line broadband higher than } 2 \\
\text { Mbps and lower than } 20 \mathrm{Mbps}\end{array}$ & \multirow[t]{2}{*}{ d.2 } & \multirow[t]{2}{*}{$\begin{array}{l}\text { Percentage of population } \\
\text { reached by fixed-line } \\
\text { broadband higher than } 20 \mathrm{Mbps}\end{array}$} & \multirow[t]{2}{*}{ d.3 } & \multirow[t]{2}{*}{ Fixed-line digital divide } \\
\hline d.4 & $\begin{array}{c}\text { Fixed-line and mobile-line digital } \\
\text { divide }\end{array}$ & & & & \\
\hline
\end{tabular}

\section{E. Cultural Heritage and Tourism}

e.1 Number of state and non-state cultural sites in 2012

e.4 Percentage of paying visitors in 2012

e.7 Number of visitors in 2015

e.10 Accommodation rate-bed places for 1000 inhabitants in 2016

e.13 Arrivals in 2016
Number of not accessible state e.2 and non-state cultural sites in 2012

Number of visitors per 1000 inhabitants in 2012

Number of visitors per 1000 inhabitants in 2015

Tourism rate-number of

e.11 presences per 1000 inhabitants in 2016

e.14 Percentage variation in arrivals between 2014 and 2016 e.3 Number of visitors in 2012

e.6 Number of state and non-state cultural sites in 2015

e.9 Accommodation rate-bed places for 1000 inhabitants in 2012

e.12

Arrivals in 2014

e.15

Presences in 2014 
Table A1. Cont.

\begin{tabular}{|c|c|c|c|c|c|}
\hline e.16 & Presences in 2016 & e.17 & $\begin{array}{l}\text { Percentage variation in } \\
\text { presences between } 2014 \text { and } \\
2016\end{array}$ & e.18 & $\begin{array}{l}\text { Percentage of presences in hotel } \\
\text { facilities in } 2016\end{array}$ \\
\hline e.19 & $\begin{array}{l}\text { Percentage of presences in extra-hotel } \\
\text { facilities in } 2016\end{array}$ & e.20 & $\begin{array}{l}\text { Percentage of arrivals in hotel } \\
\text { facilities in } 2016\end{array}$ & e.21 & $\begin{array}{l}\text { Percentage of arrivals in } \\
\text { extra-hotel facilities in } 2016\end{array}$ \\
\hline \multicolumn{6}{|c|}{ F. Health } \\
\hline f.1 & $\begin{array}{l}\text { Ambulatory specialization-medical } \\
\text { services provide per } 1000 \text { residents }\end{array}$ & f.2 & Hospitalization rate $($ LEA $=170)$ & f.3 & Over 75 hospitalization rate \\
\hline f.4 & $\begin{array}{l}\text { Avoidable hospitalization rate } \\
\qquad(\mathrm{LEA}=570)\end{array}$ & f.5 & $\begin{array}{l}\text { Percentage of over } 65 \text { residents } \\
\text { treated by integrated care home } \\
\text { assistance (ADI) }\end{array}$ & f.6 & $\begin{array}{l}\text { Number of births in which the } \\
\text { first visit is conducted after the } \\
\text { 12th week of gestation }\end{array}$ \\
\hline f.7 & $\begin{array}{l}\text { Time (minutes) passing between the } \\
\text { first call and the rescue vehicles' arrival }\end{array}$ & f. 8 & $\begin{array}{l}\text { Average number of patients per } \\
\text { doctor in } 2012\end{array}$ & f.9 & $\begin{array}{l}\text { Average number of patients per } \\
\text { pediatrician in } 2012\end{array}$ \\
\hline \multicolumn{6}{|c|}{ G. Accessibility } \\
\hline g.1 & $\begin{array}{l}\text { Municipalities' average distance in } \\
\text { minutes from the nearest center }\end{array}$ & g.2 & $\begin{array}{l}\text { Municipalities' average distance } \\
\text { in minutes from the nearest } \\
\text { center, weighted on the } \\
\text { population }\end{array}$ & g.3 & $\begin{array}{l}\text { LPT road services offer to connect } \\
\text { with the regional centers }\end{array}$ \\
\hline g.4 & $\begin{array}{l}\text { LPT road services offer to connect with } \\
\text { the local centers }\end{array}$ & g.5 & $\begin{array}{l}\text { Percentage of population } \\
\text { residing within } 15 \text { min from the } \\
\text { reference railway station }\end{array}$ & g.6 & $\begin{array}{l}\text { Percentage of population residing } \\
\text { between } 15 \text { and } 30 \text { min from the } \\
\text { reference railway station }\end{array}$ \\
\hline g.7 & $\begin{array}{l}\text { Regional rail services' intensity related } \\
\text { to the resident population able to } \\
\text { access it in less than } 15 \mathrm{~min} \text { by car }\end{array}$ & g.8 & $\begin{array}{l}\text { Regional rail services' intensity } \\
\text { related to the resident } \\
\text { population able to access it in } \\
\text { less than } 30 \text { min by car }\end{array}$ & g.9 & $\begin{array}{l}\text { Percentage of population residing } \\
\text { within } 15 \text { min from the reference } \\
\text { highway tollbooth }\end{array}$ \\
\hline g.10 & $\begin{array}{l}\text { Percentage of population residing } \\
\text { between } 15 \text { and } 30 \text { min from the } \\
\text { reference highway tollbooth }\end{array}$ & g.11 & $\begin{array}{l}\text { Percentage of population } \\
\text { residing within } 30 \text { min from the } \\
\text { reference airport }\end{array}$ & g.12 & $\begin{array}{c}\text { Percentage of population residing } \\
\text { within } 30 \text { min from the reference } \\
\text { airport }\end{array}$ \\
\hline g.13 & $\begin{array}{l}\text { Synthetic indicator of road accessibility } \\
\text { for the goods in the reference labor } \\
\text { market areas }\end{array}$ & & & & \\
\hline
\end{tabular}

\section{H. School}

\begin{tabular}{|c|c|}
\hline h.1 & $\begin{array}{l}\text { Average number of facilities per } \\
\text { educational institution }\end{array}$ \\
\hline h. 4 & $\begin{array}{l}\text { Average number of students per } \\
\text { secondary school }\end{array}$ \\
\hline h.7 & $\begin{array}{l}\text { Percentage of students resident in thei } \\
\text { primary school's municipality }\end{array}$ \\
\hline h.10 & $\begin{array}{l}\text { Percentage of multi-age classes on the } \\
\text { total of classes in primary schools }\end{array}$ \\
\hline
\end{tabular}
(2013-2014)

Invalsi: average score for the math h.14a test - 5th year primary school (2013-2014)

h.15 Number of 1st grade secondary schools h.18

Percentage of international students in 1 st grade secondary schools h.2 Number of primary schools

h.5 Percentage of international students in primary schools

$\mathrm{h} .8$

Mobility rate of permanent teachers in primary schools

h.11 Percentage of full-time classes in primary schools

Invalsi: average score for the h.13b Italian test-5th year primary school (2016-2017)

Invalsi test: average score for h.13bthe math test-5th year primary school (2016-2017)

Percentage of municipalities with 1st grade secondary schools

Ratio between children with

h.19 disabilities and support teachers in 1st grade secondary schools h.3 Percentage of municipalities with primary schools

Ratio between children between

h.6 disabilities and support teachers in primary schools

h.9 Percentage of classes with up to 15 students in primary schools

h.12 Percentage of fixed-term teachers in primary schools

Invalsi: average score for the

Italian test-5th year primary school (2016-2017) absolute values

Invalsi: average score for the math test-5th year primary school (2016-2017) absolute values

h.17 Average number of students per 1st grade secondary school

Percentage of students resident in h.20 their 1st grade secondary school's municipality 
Table A1. Cont.

\begin{tabular}{|c|c|c|c|c|}
\hline h. 21 & $\begin{array}{l}\text { Mobility rate of permanent teachers in } \\
\text { 1st grade secondary schools }\end{array}$ & h.22 & $\begin{array}{l}\text { Percentage of classes with up to } \\
15 \text { students 1st grade secondary } \\
\text { schools }\end{array}$ & $\begin{array}{l}\text { Percentage of full-time classes in } \\
\text { 1st grade secondary schools }\end{array}$ \\
\hline h. 24 & $\begin{array}{l}\text { Percentage of fixed-term teachers 1st } \\
\text { grade secondary schools }\end{array}$ & h.25a & $\begin{array}{l}\text { Invalsi: average score for the } \\
\text { Italian test-3rd year in 1st } \\
\text { grade secondary school } \\
(2013-2014)\end{array}$ & $\begin{array}{l}\text { Invalsi: average score for the } \\
\text { h.25b Italian test-3rd year in 1st grade } \\
\text { secondary school (2016-2017) }\end{array}$ \\
\hline h. $25 \mathrm{c}$ & $\begin{array}{c}\text { Invalsi: average score for the Italian } \\
\text { test-3rd year in the 1st-grade } \\
\text { secondary school (2016-2017) Absolute } \\
\text { values }\end{array}$ & h.26a & $\begin{array}{l}\text { Invalsi: average score for the } \\
\text { math test-3rd year in 1st grade } \\
\text { secondary school (2013-2014) }\end{array}$ & $\begin{array}{l}\text { Invalsi: average score for the } \\
\text { h.26b math test-3rd year in 1st grade } \\
\text { secondary school (2016-2017) }\end{array}$ \\
\hline h.26c & $\begin{array}{l}\text { Invalsi: average score for the math } \\
\text { test-3rd year in 1st grade secondary } \\
\text { school (2016-2017) absolute values }\end{array}$ & h.27 & $\begin{array}{l}\text { Number of 2nd grade } \\
\text { secondary schools }\end{array}$ & $\begin{array}{c}\text { h.28 Percentage of municipalities with } \\
\text { 2nd grade secondary schools }\end{array}$ \\
\hline h. 29 & $\begin{array}{l}\text { Average number of students per 2nd } \\
\text { grade secondary school }\end{array}$ & h.30 & $\begin{array}{l}\text { Percentage of international } \\
\text { students in 2nd grade } \\
\text { secondary schools }\end{array}$ & $\begin{array}{c}\text { Percentage of students residing in } \\
\text { h.31 their 2nd grade secondary } \\
\text { school's municipality }\end{array}$ \\
\hline h.32 & $\begin{array}{l}\text { Mobility rate of permanent teachers in } \\
\text { 2nd grade secondary schools }\end{array}$ & h.33 & $\begin{array}{l}\text { Percentage of fixed-term } \\
\text { teachers 2nd grade secondary } \\
\text { schools }\end{array}$ & $\begin{array}{l}\text { Invalsi: average score for the } \\
\text { Italian test-2nd year in 2nd } \\
\text { grade secondary school } \\
(2013-2014)\end{array}$ \\
\hline h.34b & $\begin{array}{l}\text { Invalsi: average score for the Italian } \\
\text { test-2nd year in 2nd grade secondary } \\
\text { school (2016-2017) }\end{array}$ & h.34c & $\begin{array}{l}\text { Invalsi: average score for the } \\
\text { Italian test-2nd year in } 2 \text { nd } \\
\text { grade secondary school } \\
\text { (2016-2017) absolute value }\end{array}$ & $\begin{array}{l}\text { Invalsi: average score for the } \\
\text { h.35a math test-2nd year in 2nd grade } \\
\text { secondary school (2013-2014) }\end{array}$ \\
\hline h.35b & $\begin{array}{l}\text { Invalsi: average score for the math } \\
\text { test-2nd year in 2nd grade secondary } \\
\text { school (2016-2017) }\end{array}$ & h.35c & $\begin{array}{l}\text { Invalsi: average score for the } \\
\text { math test-2nd year in } 2 \text { nd } \\
\text { grade secondary school } \\
(2016-2017) \text { absolute value }\end{array}$ & \\
\hline
\end{tabular}

\section{Cooperation Among Municipalities}

i.1 Number of municipalities in a municipalities union

i.4

Percentage of municipalities in a mountain community

i.7

Percentage of municipalities included in an area plan $(\mathrm{PdZ})$ i. 2

i.5

Number of municipalities in a convention/consortium

Percentage of municipalities included in an area plan

belonging to the inner area on the total of the regional municipalities included in an i.3

Number of municipalities in a mountain community

i.6

Percentage of municipalities in a convention/consortium area plan the PCA

\section{References}

1. Lucatelli, S. Riflessioni sulle Aree Interne, all'indomani del Covid-19. In Aree Interne e Covid; Fenu, N., Ed.; LetteraVentidue: Siracusa, Italy, 2020; pp. 12-23.

2. Sharifi, A.; Khavarian-Garmsir, A.R. The COVID-19 pandemic: Impacts on cities and major lessons for urban planning, design and management. Sci. Total Environ. 2020, 749, 142391. [CrossRef] [PubMed]

3. De Rossi, A. Introduzione. L'inversione dello sguardo. Per una nuova rappresentazione territoriale del paese Italia. In Riabitare l'Italia. Le aree Interne tra ab-Bandoni e Riconquiste; De Rossi, A., Ed.; Donzelli Editore: Roma, Italy, 2018; pp. 3-17.

4. European Union. Treaty of Lisbon. Amending the Treaty on European Union and the Treaty Establishing the European Community (2007/C 306/01). OJEU 2007, 50, 84-85. Available online: https:/ / eur-lex.europa.eu/LexUriServ /LexUriServ.do? uri=OJ:C:2007:306:FULL:EN:PDF (accessed on 18 March 2021).

5. Demeterova, B.; Fischer, T.; Schmude, J. The Right to Not Catch Up-Transitioning European Territorial Cohesion towards Spatial Justice for Sustainability. Sustainability 2020, 12, 4797. [CrossRef] 
6. Salez, P.; Lucatelli, S. La Dimensione Territoriale nel Prossimo Periodo di Programmazione. Available online: https:// agriregionieuropa.univpm.it/it/content/article/31/31/la-dimensione-territoriale-nel-prossimo-periodo-di-programmazione (accessed on 18 March 2021).

7. Cotella, G.; Vitale Brovarone, E. The Italian National Strategy for Inner Areas: A Place-Based Approach to Regional Development. In Dilemmas of Regional and Local Development; Banski, J., Ed.; Routledge: Abingdon-on-Thames, UK, 2020.

8. Rosik, P.; Stepniak, M.; Komornicki, T. The decade of the big push to roads in Poland: Impact on improvement in accessibility and territorial cohesion from a policy perspective. Transp. Policy 2015, 37, 134-146. [CrossRef]

9. Medeiros, E. European Union Cohesion Policy and Spain: A territorial impact assessment. Reg. Stud. 2017, 51, 1259-1269. [CrossRef]

10. Asprogerakas, E. The EU territorial cohesion discourse and the spatial planning system in Greece. Eur. Plan. Stud. 2019, 28, 583-603. [CrossRef]

11. Lucatelli, S.; Luisi, D. La Strategia Nazionale delle aree interne a tre anni dall'avvio. Urbantracks 2018, $26,24-29$.

12. Basile, G.; Cavallo, A. Rural identity, authenticity, and sustainability in Italian inner areas. Sustainability 2020, 12, 1272. [CrossRef]

13. Rossitti, M.; Torrieri, F. Circular economy as catalyst for resilience in inner areas. SMC 2021, Special Issue 4 in press.

14. Relazione Annuale Sulla Strategia Nazionale per le Aree Interne (31 December 2018). Available online: https://www. agenziacoesione.gov.it/news_istituzionali/lavanzamento-della-snai-presentata-la-relazione-al-cipe-per-il-2018/ (accessed on 25 March 2021).

15. Carrosio, G. A place-based perspective for welfare recalibration in the Italian inner peripheries: The case of the Italian Strategies for inner areas. Sociol. Politiche Soc. 2016, 19, 50-64. [CrossRef]

16. Barca, F.; Casavola, P.; Lucatelli, S. Strategia Nazionale Per le Aree Interne. Definizioni, Obiettivi e Strumenti di Governance. Mater. UVAL 2014, 31, 10. Available online: https://www.regione.fvg.it/rafvg/export/sites/default/RAFVG/economia-imprese/ montagna/FOGLIA14/allegati/obiettiviStrumentiEgovernancePerLeAreeInterne.pdf (accessed on 18 March 2021).

17. Carrosio, G.; Faccini, A. Le mappe della cittadinanza nelle aree interne. In Riabitare l'Italia. Le Aree Interne Tra ab-Bandoni e Riconquiste; De Rossi, A., Ed.; Donzelli Editore: Roma, Italy, 2018; pp. 51-77.

18. Dipartimento per lo Sviluppo e la Coesione Economica, Le Aree Interne: Di Quali Territori Parliamo? In Nota Esplicativa Sul Metodo di Classificazione Delle Aree. Available online: http:/ / www301.regione.toscana.it/bancadati/atti/Contenuto.xml?id=5081 285\&nomeFile=Delibera_n.32_del_20-01-2014-Allegato-A (accessed on 19 March 2021).

19. De Matteis, G. Montagne e aree interne nelle politiche di coesione territoriale italiane ed europee. Territorio 2013, 66, 7-15. [CrossRef]

20. Lucatelli, S. La Strategia Nazionale, il riconoscimento delle aree interne. Territorio 2015, 74, 80-86. [CrossRef]

21. Tantillo, F.; Lucatelli, S. La Strategia nazionale per le aree interne. In Riabitare l'Italia. Le Aree Interne Tra ab-Bandoni e Riconquiste; De Rossi, A., Ed.; Donzelli Editore: Roma, Italy, 2018; pp. 403-416.

22. Carlucci, C.; Lucatelli, S. La Strategia Aree Interne 2014-2020: Dati e Indicatori Pertinenti. In Statistiche Per le Politiche di Sviluppo a Supporto dei Decisori Pubblici, Proceedings of the Conference Statistiche Per le Politiche di Sviluppo a Supporto Dei Decisori Pubblici, Roma, Italy, 7 July 2015; Iaco, D., Ed.; ISTAT: Roma, Italy, 2016; pp. 173-186. Available online: https://www4.istat.it/it/files/2016/08/ ebook-politiche-di-sviluppo.pdf (accessed on 19 March 2021).

23. Rittel, H.W.J.; Webber, M.M. Dilemmas in a General Theory of Planning. Policy Sci. 1973, 4, 155-169. [CrossRef]

24. Barca, F. An Agenda for a Reformed Cohesion Policy. A Place-Based Approach to Meeting European Union Challenges and Expectations; Eeri: Bruxelles, Belgium, 2009.

25. Daganzo, C.F.; Gayah, V.V.; Gonzales, E.J. The potential of parsimonious models for understanding large scale transportation systems and answering big picture questions. EJTL 2012, 1, 47-65. [CrossRef]

26. Abastante, F.; Corrente, S.; Greco, S.; Ishizaka, A.; Lami, I.M. Choice architecture for architecture choices: Evaluating social housing initiatives putting together a parsimonious AHP methodology and the Choquet integral. Land Use Policy 2017, 78, 748-762. [CrossRef]

27. Basaran, D.; Ntoutsi, E.; Zimek, A. Redundancies in Data and their Effect on the Evaluation of Recommendation Systems: A Case Study on the Amazon Reviews Datasets. In Proceedings of the 2017 SIAM International Conference on Data Mining (SDM), Houston, TX, USA, 27-29 April 2017; Chawla, N., Wang, W., Eds.; SIAM: Philadelphia, PA, USA, 2017. [CrossRef]

28. Huang, Z.; Chen, J.; Yisong, L. Minimizing data redundancy for high reliable cloud storage systems. Comput. Netw. 2015, 81, 164-177. [CrossRef]

29. Agenzia Per la Coesione Territoriale. Indicators for the "Open Diagnosis" of the Project Areas: Indicators Used in the Investigation Process. Available online: https://www.agenziacoesione.gov.it/strategia-nazionale-aree-interne/la-selezione-delle-aree/ (accessed on 19 March 2021).

30. Shi, Y.; Yang, J.; Shen, P. Revealing the Correlation between Population Density and the Spatial Distribution of Urban Public Service Facilities with Mobile Phone Data. ISPRS Int. J. Geo-Inf. 2020, 9, 38. [CrossRef]

31. Asuero, A.G.; Sayago, A.; Gonzalez, A.G. The Correlation Coefficient: An Overview. Crit. Rev. Anal. Chem. 2006, 36, 41-59. [CrossRef]

32. Archdeacon, T.J. Correlation and Regression Analysis: A Historian's Guide; University of Wisconsin Press: Madison, WI, USA, 1994.

33. Popovich, P.M.; Chen, P.Y. Correlation: Parametric and Nonparametric Measures; Sage Publications: Thousand Oaks, CA, USA, 2002. 
34. Hair, J.F.; Black, W.C.; Babin, B.J.; Anderson, R.E.; Tatham, R.L. Multivariate Data Analysis, 6th ed.; Pearson Prentice Hall: Upper Saddle River, NJ, USA, 2006.

35. Correa-Parra, J.; Vergara-Perucich, J.; Aguirre-Nunez, C. Towards a Walkable City: Principal Component Analysis for Defining Sub-Centralities in the Santiago Metropolitan Area. Land 2020, 9, 362. [CrossRef]

36. Manly, B. Multivariate Statistical Methods; Chapman \& Hall: London, UK, 1994.

37. OECD-JRC. Handbook on Constructing Composite Indicators. Methodology and User Guide; OECD: Paris, France, 2008 ; pp. 66-67. Available online: https://www.oecd.org/els/soc/handbookonconstructingcompositeindicatorsmethodologyanduserguide.htm (accessed on 23 March 2021).

38. Lawley, D.N.; Maxwell, A.E. Factor Analysis as a Statistical Method; Butterworth and Co.: London, UK, 1971.

39. Kim, J.; Mueller, C.W. Factor Analysis: Statistical Methods and Practical Issues; Sage Publications: Beverly Hills, CA, USA, 1978; p. 88.

40. Saha, P.; Roy, N.; Mukherjee, D.; Sarkar, A.S. Application of Principal Component Analysis for Outlier Detection in Heterogeneous Traffic Data. Procedia Comput. Sci. 2016, 83, 107-114. [CrossRef]

41. Russell, D.W. In Search of Underlying Dimensions: The Use (and Abuse) of Factor Analysis. Pers. Soc. Psychol. Bull. 2002, 28, 1629-1646. [CrossRef]

42. Dunteman, G.H. Principal Components Analysis; Sage Publications: Thousand Oaks, CA, USA, 1989.

43. Yong, A.G.; Pearce, S. A beginner's guide to Factor Analysis: Focusing on Exploratory Factor Analysis. Tutor. Quant. Methods Psychol. 2013, 9, 79-94. [CrossRef]

44. Giacomini, D.; Sancino, A.; Simonetto, A. The introduction of mandatory inter-municipal cooperation in small municipalities: Preliminary lessons from Italy. Int. J. Public Sect. Manag. 2018, 31, 341-346. [CrossRef]

45. Hanuhek, E.; Sarpca, S.; Yilmaz, K. Private Schools and Residential Choices: Accessibility, Mobility and Welfare. BE J. Econ. Anal. Policy 2011, 11, 243-261. [CrossRef]

46. Hanuhek, E.; Yilmaz, K. Land-use Controls, Fiscal Zoning, and the Local Provision of Education. PFR 2015, 43, 559-585. [CrossRef]

47. Duhr, S.; Muller, A. The Role of Spatial Data and Spatial Information in Strategic Spatial Planning. Reg. Stud. 2012, 46, 423-428. [CrossRef]

48. Brunetta, G.; Salata, S. Mapping Urban Resilience for Spatial Planning-A First Attempt to Measure the Vulnerability of the System. Sustainability 2019, 11, 2331. [CrossRef]

49. Caparros Martinez, J.L.; Garcia, J.M.; Lopez, N.R.; de Pablo Valenciano, J. Mapping green infrastructure and socioeconomic indicators as a public management tool: The case of the municipalities of Andalusia (Spain). Environ. Sci. Eur. 2020, $32,144$. [CrossRef]

50. Guarini, M.R.; Battisti, F.; Chiovitti, A. A Methodology for the Selection of Multi-Criteria Decision Analysis Methods in Real Estate and Land Management Processes. Sustainability 2018, 10, 507. [CrossRef]

51. Oppio, A.; Dell'Ovo, M. Cultural heritage preservation and territorial attractiveness. A spatial multi-dimensional evaluation approach. In Cycling \& Walking for Regional Development. How Slowness Regenerates Marginal Areas; Pileri, P., Moscarelli, R., Eds.; Springer: Cham, Switzerland, 2021; pp. 105-125. [CrossRef]

52. Smith, J.P.; Meerow, S.; Turner, B.L., II. Planning urban community gardens strategically through multicriteria decision analysis. Urban For. Urban Green. 2021, 58, 126897. [CrossRef]

53. Vecco, M. A Definition of Cultural Heritage: From the Tangible to the Intangible. J. Cult. Herit. 2010, 11, 321-324. [CrossRef]

54. Barca, F. Alternative Approaches to Development Policy: Intersections and Divergencies. In OECD Regional Outlook. Building Resilient Regions for Stronger Economies; OECD Publishing: Paris, France, 2011; pp. 215-225. [CrossRef]

55. Worrall, R.; O'Leary, F. Towards greater collective impact: Building collaborative capacity in Cork city's LCDC. Administration 2020, 68, 37-58. [CrossRef]

56. Crosta, P.L. Pratiche. Il Territorio «è l'uso che se ne fa»; FrancoAngeli: Milano, Italy, 2010.

57. Stanghellini, S. Un approccio integrato alla rigenerazione urbana. Urbanistica 2019, 160, 8-15.

58. Oppio, A. Migranti e aree interne per una strategia anti-fragilità. Valori Valutazioni 2021, 28, in press. 